\title{
Monitoring Intensity and Stakeholders' Orientation: How Does Governance Affect Social and Environmental Disclosure?
}

\author{
Christine Mallin • Giovanna Michelon • \\ Davide Raggi
}

Received: 19 October 2011/Accepted: 11 April 2012

(C) Springer Science+Business Media B.V. 2012

\begin{abstract}
The aim of the paper is to investigate the effects of the corporate governance model on social and environmental disclosure (SED). We analyze the disclosures of the 100 U.S. Best Corporate Citizens in the period 2005-2007, and we posit a series of simultaneous relationships between different attributes of the governance system and a multidimensional construct of corporate social performance (CSP). We consider both the extent and the quality of SED, with the purpose of identifying increasing levels of corporate commitment to stakeholders and shedding some light on whether SED is used as a signal or rather as a legitimacy tool. Our empirical evidence shows that the stakeholders' orientation of corporate governance is positively associated with CSP and SED. On the other hand, we do not find support for the monitoring intensity of corporate governance being negatively associated with social performance. We also find that CSP in the "product" dimension is positively associated with the extent and quality of SED whilst CSP in the "people" dimension is negatively associated with the extent and quality of SED. At a time when shareholders and stakeholders share more common aspects in their relationships
\end{abstract}

C. Mallin $(\bowtie)$

Birmingham Business School, University of Birmingham, University House, Edgbaston, Birmingham B15 2TT, UK

e-mail: c.a.mallin@bham.ac.uk

G. Michelon

Department of Economics and Management, University

of Padova, via del Santo 33, 35123 Padova, Italy

e-mail: giovanna.michelon@unipd.it

D. Raggi

Department of Economics, University of Bologna,

Piazza Scaravilli 2, 40126 Bologna, Italy

e-mail: davide.raggi@unibo.it with firms, this is a significant area to explore and this research fills an important lacuna in this respect.

Keywords Corporate governance $\cdot$ Corporate social responsibility - Social and environmental disclosure . Monitoring $\cdot$ Structural equation modeling

\section{Introduction}

International organizations (OECD 2004, 2010; Global Corporate Governance Forum 2009) and institutional investors (such as Aviva, Hermes, CalPERS) are asking companies to incorporate social and environmental responsibilities in their core decision making processes, based mainly on the argument that incorporation of these "new" dimensions will lead to long-term value (i.e., the business case argument). They argue that, especially after the recent global financial crisis, corporate boards of directors should provide wellinformed strategic direction and engaged oversight beyond short-term financial performance. By so doing, companies would more comprehensively address risks by anticipating actions with a potentially adverse impact on society and the environment and thus better manage reputational risks whilst also potentially identifying new business opportunities.

Such vision calls for new responsibilities of boards collectively and directors individually both in terms of corporate activities and accountability. This impetus on a new understanding of the role of boards can be found in a growing number of global and industry specific initiatives such as the OECD Principles of Corporate Governance and the UN Global Compact. The OECD Principles call on businesses to recognize and safeguard stakeholders' rights, including legitimate interests and information needs. These Principles call on boards to be truly accountable to 
shareowners and to take ultimate responsibility for their firm's adherence to a high standard of corporate behavior and ethics. This call is in line with academic research on boards' contribution to corporate strategy (e.g., Pugliese et al. 2007) and with the claim that adequate board composition, structure, and internal processes are necessary to promote an effective contribution of the board of directors to strategy (Minichilli et al. 2009). Although the academic literature has widely investigated the determinants of social and environmental strategy and disclosure (Johnson and Greening 1999; Luoma and Goodstein 1999; Gray et al. 1995; Cho and Patten 2007; Clarkson et al. 2008; Cho et al. 2010), little research effort has been made to analyze how the board of directors might affect accountability policies (e.g., Haniffa and Cooke 2005; Michelon and Parbonetti 2010).

Drawing on a wide range of studies on the determinants of social and environmental disclosure (SED), the aim of this paper is to investigate whether a corporate governance path leading to SED can be traced, by considering the interplays between different governance attributes and corporate social performance (CSP). In order to do so, we analyze the disclosures of the 100 U.S. Best Corporate Citizens in the period 2005-2007 and we posit a series of simultaneous relationships between different attributes of the governance system and a multidimensional construct of CSP.

First, we develop holistic measures of both monitoring intensity and stakeholders' orientation of corporate governance. Then, we test whether these two attributes of the corporate governance system affect simultaneously the two dimensions of social performance (people and product). Finally, by considering both the extent and the quality of SED (with the purpose of identifying increasing levels of corporate commitment to stakeholders) we are able to shed some light on whether SED is used to signal their superior performance or rather as a legitimacy tool to cover up poor performance. By considering simultaneously the extent and the quality of SED we are able to detect whether a poorly performing company is providing more extensive information on CSP, than its good performing peer, but of lower quality, i.e., no quantitative or financial data (Guidry and Patten 2010).

The research has important implications in a number of areas. Firstly it merges together three strands of the literature: governance, CSP, and SED, showing that a more holistic approach can lead to a more complete interpretation of complex phenomena; secondly it gives new insights into the different roles that the governance system might play in both socially responsible practices and disclosure; and thirdly it develops and explores a 'governance path' for SED. At a time when shareholders and stakeholders share more common aspects in their relationships with firms, this is a significant area to explore and this research fills an important lacuna in this respect. By trying to disentangle the complex governance path to SED, we are providing international organizations and institutional investors with a better view of how governance can affect the setting of social and environmental objectives and enhance accountability in relation to the performance of these objectives.

The remainder of the paper is organized as follows. The next section reviews the literature and develops the research hypotheses. The research method section presents the sample, measures, and methodology. The results are then presented and discussed. The conclusion section gives an overview of the empirical findings and draws the main contributions and implications of this study.

\section{Theoretical Framework and Hypotheses}

\section{Governance and CSP}

The board of directors is traditionally assigned with two important roles: the monitoring (control role) and the advising (service role) (Hillman and Dalziel 2003). Although they are contemporaneous roles played by the board, how these two functions relate to CSP have only been studied separately.

The monitoring function has been mainly analyzed following agency theory (Jensen and Meckling 1976; Fama and Jensen 1983), according to which internal and external governance mechanisms are set with the objective of monitoring management's behavior on behalf of shareholders, given the potential for conflicts of interest arising with the separation of ownership and control (Berle and Means 1932). Following this perspective, there are several characteristics of the governance model that enhance the monitoring intensity, for example, within the board of directors, considered the most important internal governance mechanism (Jensen and Meckling 1976), we can identify the presence of independent directors and the separation between the CEO and the Chairman as enhancements. The literature (e.g., Gillan 2006) also discusses the monitoring role played by ownership structure, in terms of both the ownership concentration and the presence of institutional investors. ${ }^{1}$

Within this theoretical framework, Cespa and Cestone (2007) and Surroca and Tribò (2008) argue that CSR is used by management as an entrenchment strategy, in order

\footnotetext{
${ }^{1}$ A discussion of how these characteristics are linked to monitoring intensity is beyond the scope of this paper. For a review of the literature on various monitoring mechanisms, please refer to Gillan (2006). Moreover, the ability of these separate characteristics to proxy for the monitoring intensity of the governance structure is an empirical issue and it will be addressed using a latent variable in the empirical model later in the paper.
} 
to gather support from stakeholders. Following this line of reasoning, incumbent managers and stakeholders would be natural allies because collaboration with stakeholders cannot easily be blocked by individual shareholders, if based only on a 'suspicious' entrenchment strategy. This stimulates managers' incentives to improve CSP with entrenchment intentions (Cespa and Cestone 2007). Nevertheless, the monitoring intensity of the governance model adopted by the firm should also constrain managerial discretion. This would hinder the implementation of expensive socially responsible activities. That is, the monitoring function of the board and ownership is expected to have a negative direct effect on a firm's CSP. At the empirical level, Coffey and Wang (1998) find evidence of the managerial control thesis, and suggest that "a substantial component of charitable giving can be ultimately traced to instrumental motives" (p. 1601). Similarly, Surroca and Tribò (2008) find that variables measuring the monitoring intensity of the governance model (such as the proportion of independent directors, the separation between the CEO and the Chairman and the presence of independent committees) are negatively associated with CSP. Therefore in line with agency theory, we posit the following hypothesis:

H1 The monitoring intensity of corporate governance is negatively associated with social performance.

The focus on the advising role of the board is the perspective adopted in the resource dependence (Pfeffer and Salancik 1978; Hillman et al. 2000) and stakeholders' research (Johnson and Greening 1999; Luoma and Goodstein 1999; Hillman et al. 2001; Huse 2003).

Within this approach, besides monitoring capabilities, directors sitting on the board bring critical resources to the company in terms of knowledge, ties, and legitimacy. Since companies might have incentives to design governance structures aimed at satisfying the interests of critical stakeholders (Zattoni 2011), the level of stakeholder orientation of the firm's governance is coherent with a model of extended corporate social responsibility in which those who run the firm are responsible for fulfilling their fiduciary duties towards all stakeholders (Sacconi 2006). Within this line of reasoning, resource dependence theory will help us in defining what characteristics of the governance structure might be indicative of an orientation towards stakeholders of the firm, because the resources brought by the directors will be for the firm's use to implement stakeholder oriented strategies. This idea is linked to the work of Zahra and Pearce (1989, p. 297), according to which corporate boards act as 'boundary spanners' and perform many roles at the same time, providing four types of benefits to the firm: advice and counseling (Mintzberg 1983); legitimacy (Selznick 1949); channels for communicating information between external organizations and the company (Hillman et al. 2000) and preferential access to commitments or support from important stakeholders in the company's environment (Hillman et al. 2001). Thus, directors may do more than reduce uncertainty (Hillman et al. 2000), as they bring resources and legitimacy to the company (Gales and Kesener 1994). Zattoni $(2011$, p. 268) argues that "a board representing stakeholders' groups that provide critical contributions has higher decision-making abilities and can achieve a cooperative bargaining agreement among all constituents". Within this framework, the reputation of the directors in the community and among stakeholders enables the company to carry on its business and actions (Zattoni 2011), mobilize external support and resources, and enhance organizational legitimacy (Provan 1980; Deephouse 2000) and thus lead to increased social performance (Mallin and Michelon 2011).

A service role with respect to stakeholders is also ascribed to the ownership of companies. Johnson and Greening (1999) posit the existence of a positive relationship between the level of pension funds' ownership and social performance, mainly relying on the fact that pension funds' managers "are not subject to the same short-term pressures as investment managers and they therefore have longer time horizons" (p. 567) which allows for a greater compatibility between an institutional owner's time horizon and the time needed to realize the benefits of investment in CSP (Johnson and Greening 1999; Graves and Waddock 1994). Similar arguments are used by Cox et al. (2004) who find that long-term institutional ownership appears to discriminate between CSP attributes favoring employees related CSP rather than community and the environment and that they are more likely to apply negative screens for selecting companies on the basis of CSP, so the worst performers are excluded from the investment decisions of long-term institutional investors. Subsequently, Neubaum and Zahra (2006) find that the volume of long-term pension fund holdings is positively associated with CSP and that, although "activism itself is not associated with CSP in a significant way, its interaction with long-term institutional holdings is significantly and positively associated with CSP" (p. 125). Their empirical evidence thus suggests that the presence and salience of institutional long-term ownership might promote corporate support for engaging in socially responsible activities. This is in line with the arguments of Zattoni (2011) who argues that the assignment of ownership rights to stakeholders supplying critical contributions could affect the value creation process of the firm.

Along this line of reasoning, we posit that both the board of directors and the ownership structure of the company play a role in addressing corporate stakeholders' orientation. Thus, we develop the following hypothesis: 
H2 The stakeholder orientation of corporate governance is positively associated with social performance.

\section{CSP and SED}

Many studies investigated this relationship, with different underlying theoretical frameworks, predictions, and results (Bowman and Haire 1975; Abbott and Monsen 1979; Freedman and Jaggi 1982; Ullman 1985; Belkaoui and Karpik 1989; Roberts 1992; Patten 2002; Al-Tuwaijri et al. 2003; Cho and Patten 2007; Clarkson et al. 2008; Cho et al. 2010)

Socio-political theories of SED (see, e.g., Guthrie and Parker 1990; Patten 1991, 1992; Lindblom 1994; Gray et al. 1995; Hackston and Milne 1996; Cho et al. 2006) suggest that the extent of this disclosure is a "function of exposure to public pressure in the social/political environment" (Patten 2002, p. 763). In other words, according to this approach, the worst performers would be expected to provide greater disclosure and thus a negative relationship between disclosure and performance should be posited. Similar arguments are brought up by litigation cost theory, as "if greater disclosure provides information that may be used in litigation against the disclosing firm (presumably by third parties with political or social agendas), good environmental performers might elect to minimize such disclosure" (Al-Tuwaijri et al. 2003). Based on the discussion above, we offer the following directional hypothesis:

H3 Corporate social performance is negatively associated with the extent of social and environmental disclosure.

In line with agency theory, when a company engages in socially responsible activities, which most likely involve the use of resources, it may be interpreted as a way to create an image of sensitivity to important influences, which do not belong to the market, but that can still be in the long-term interests of shareholders (Abbott and Monsen 1979; Freeman 1984). Assuming managers are willing to reveal their social engagement to both stakeholders and shareholders, one way to communicate it is through some form of SED (Belkaoui and Karpik 1989), as good social and environmental performance should reduce the company's exposure to future risks and thus this information should be perceived as good news by investors. In this sense, companies may use SED to signal their commitment to external stakeholders (i.e., SED is used as a "signal").

Al-Tuwaijri et al. (2003) find that good environmental performers disclose more environmental information than do poor performers in line with the prediction of Verecchia's (1983) discretionary disclosure model. In a similar vein, Clarkson et al. (2008) find that "superior environmental performers are more forthcoming in truly discretionary disclosure channels, as predicted by the economics based voluntary disclosure theory" (p. 305). If agency theory predictions hold true, we expect that a higher quality of SED, which are supposedly more credible, will be provided by the best performers in order to signal their true type and real commitment to CSR. Therefore we develop the following hypothesis:

H4 Corporate social performance is positively associated with the quality of social and environmental disclosure.

\section{A Governance Path for Social and Environmental Disclosure?}

While each of the relationships analyzed above has received considerable attention, we have much to learn about the joint impact of corporate governance and CSP on SED (Haniffa and Cooke 2005; Michelon and Parbonetti 2010), especially considering that studies focusing on social performance and disclosure have brought up mixed evidence. Thus, based on the previous literature review, we expect that the interplay between the characteristics of the corporate governance model adopted by the company and CSP (Mallin and Michelon 2011) is a fundamental determinant of companies' disclosures.

Bondy et al. (2008) investigate whether the adoption of codes, including corporate governance codes, by firms is associated with the firms' CSR practices. They find that "codes are not primarily used as governance tools for CSR commitments but are used as governance tools for other issues such as those requiring compliance" (p. 295). Furthermore, they state "it would in fact appear that codes are more often used as tools for governing traditional business issues such as ensuring compliance with laws and regulations, improving the corporation's reputation, and guiding employees in terms of expected workplace behavior" (p.,302). However, Buckholtz et al. (2008) place more emphasis on the role of corporate governance, for example, they state "Boards are responsible for more than monitoring the CEO's behavior - they must share in the leadership of the firm to insure that the firm fulfills its economic, legal, ethical, and discretionary social responsibility to the firm" (p. 340). Therefore, we develop a model that aims at disentangling the complex path to SED. Figure 1 presents a model of the hypothesized antecedents of SED.

The model depicts the governance system as two latent concepts: they are the monitoring intensity (Jensen and Meckling 1976) and stakeholders' orientation (Ullman 1985) of the governance model. Following Johnson and Greening (1999), we believe CSP is a multidimensional concept and thus using an overall (aggregated) measure of social performance may mask the individual dimensions 


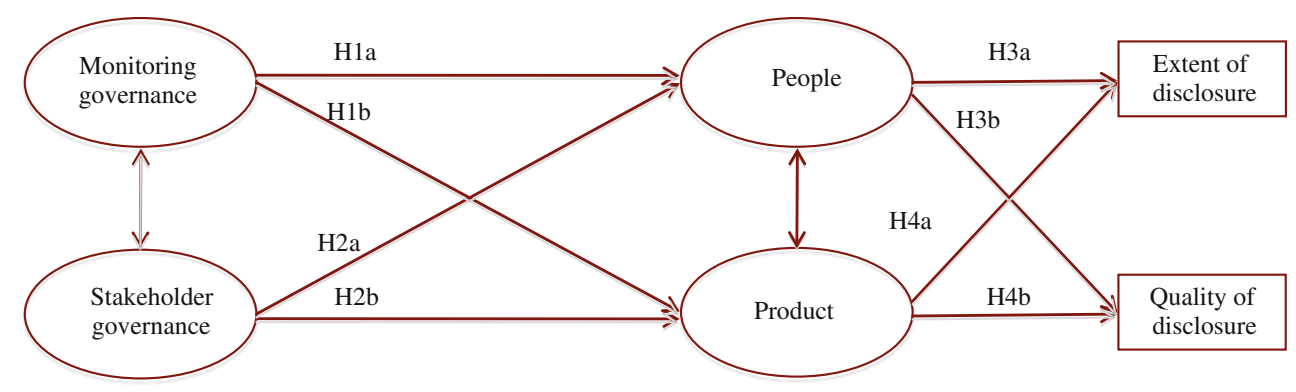

Fig. 1 Theoretical model

that are equally important and relevant. They argue that there are at least two conceptually distinct dimensions: people (relating to the contributions firms make to communities, employees and society in general) and product (relating to product and service quality and responsibility and to the firm's stance toward the natural environmentenvironmentally conscious products). We follow their line of reasoning and we adopt the constructs identified by Johnson and Greening (1999). The model takes into consideration two latent variables depicting social (people) and environmental (product) performance. Thus, there are four sets of hypotheses: two of the sets hypothesize a relationship between the latent governance variables and the latent CSP variables, whilst two of the sets relate this path to quantity and quality of information. Our four hypotheses are therefore split up into four pairs of links (H1a, H1b; H2a, H2b; H3a, H3b; H4a, H4b).

The signs we expect are summarized in Table 1. Following the entrenchment literature based on agency theory, more monitoring intensity of corporate governance should be associated with less CSR activities and thus lower CSP, whilst a more stakeholder oriented governance should improve CSP. If the legitimacy argument pursued in the accounting literature holds true, then more disclosure should be provided by the worst performers as a legitimacy strategy, but if the agency theory predictions also hold true, then we expect that higher quality disclosure, which supposedly is more credible, should be provided by the best performers who want to signal their true commitment, indicating that disclosure is used as an accountability mechanism.

\section{Research Method}

Sample

The initial sample for this study consists of the 100 companies listed in the Business Ethics 100 Best Corporate Citizens for the years 2005, 2006, and 2007. The rank is built on the KLD overall social performance rating
Table 1 Hypotheses

\begin{tabular}{|c|c|c|}
\hline Hypotheses & Description of paths & $\begin{array}{l}\text { Hypothesized } \\
\text { sign }\end{array}$ \\
\hline $1 \mathrm{a}$ & $\begin{array}{l}\text { Monitoring governance } \rightarrow \text { people } \\
\text { dimension }\end{array}$ & - \\
\hline $1 b$ & $\begin{array}{l}\text { Monitoring governance } \rightarrow \text { product } \\
\text { dimension }\end{array}$ & - \\
\hline $2 \mathrm{a}$ & $\begin{array}{l}\text { Service governance } \rightarrow \text { people } \\
\text { dimension }\end{array}$ & + \\
\hline $2 b$ & $\begin{array}{l}\text { Service governance } \rightarrow \text { product } \\
\text { dimension }\end{array}$ & + \\
\hline $3 a$ & $\begin{array}{l}\text { People dimension } \rightarrow \text { extent of } \\
\text { disclosure }\end{array}$ & - \\
\hline $3 b$ & $\begin{array}{l}\text { People dimension } \rightarrow \text { quality of } \\
\text { disclosure }\end{array}$ & + \\
\hline $4 a$ & $\begin{array}{l}\text { Product dimension } \rightarrow \text { extent of } \\
\text { disclosure }\end{array}$ & - \\
\hline $4 b$ & $\begin{array}{l}\text { Product dimension } \rightarrow \text { quality of } \\
\text { disclosure }\end{array}$ & + \\
\hline
\end{tabular}

obtained as the average of the ratings in seven CSP areas: Community, Corporate Governance, Diversity, Employee Relations, Environment, Human Rights, and Product Quality and Safety. ${ }^{2}$

The choice of this sample is driven by the findings of Cox et al. (2004), according to which long-term institutional investors select, through exclusion, the worst social performers. Thus, by considering companies in the list of Best Corporate Citizens, we are able to identify whether the presence of institutional investors is in fact able to lead to better social performance.

\footnotetext{
${ }^{2}$ Whilst belonging to the list of the Best Corporate Citizens, these companies present both strengths and weaknesses as the ratings present both positive and negative values. Thus, KLD's social performance data of the Top 100 Best Corporate Citizens provides a great degree of variability in the behavior of the firms. Moreover by using a period of 3 years $(2005,2006$, and 2007) we are able to analyze the company's longer-term social performance. Nonetheless, we recognize that the generalization of the findings of the study may be limited given the fact that the sample consisted of the most highly rated companies.
} 
Given that some companies were listed for more than 1 year in succession whilst others were listed for only 1 year and that we lost some observations because of lack of data, the total number of observations is 221 and the total number of companies is 135 . For each company and year, archival data about ownership, board composition and CSR performance are collected as follows.

\section{Measures of Social and Environmental Disclosure}

The extent of SED is determined using the content analysis method, a line of research widely adopted to ensure reliability and valid inferences from narrative data in accordance with their context (Krippendorff 2004). Following coding, quantitative scales are derived to permit further analysis. This method has been widely adopted in previous social responsibility disclosure studies (see, e.g., Hackston and Milne 1996).

We measure SED in two ways in order to depict different disclosure choices made by companies, that we argue depict an increasing level of commitment to communication.

First, we employ a measure of disclosure which, we believe, allows us to test the adoption of a multi-stakeholder reporting framework that forces companies to report according to the triple bottom line (economic, social, and environmental) and requires managers to analyze all stakeholders' expectations and to discuss the positive or negative replies provided by the company's operations and performances. The reporting framework for the content analysis refers to the GRI standards: we verify how many indicators (out of a maximum of 121) of those suggested by the GRI the company reports on. A particular sentence is chosen as the recording unit to overcome problems related to the use of words or portions of pages that add unreliability. Thus, each sentence is matched with all 121 sustainability disclosure items and is coded as follows: with a score of 0 if it provides no information; with a score of 1 if it discloses information. The level of disclosure is measured by counting the presence of items. The content analysis is performed using the annual social, environmental and sustainability reports of the companies. Our proxy for the extent of disclosure is obtained as the adherence to the GRI standards, i.e., by dividing the total number of items by the maximum possible (121). This measure ranges from 0 (no GRI indicators are reported) to 1 (all GRI indicators are reported). This measure was collected for all companies issuing a sustainability report, even when they do not explicitly declare that they adhere to the GRI guidelines. If a company does not have a sustainability stand-alone report this measure is set equal to zero.

Second, we employ a measure for the quality of disclosure. Following the coding scheme proposed by Guidry and Patten (2010) we perform content analysis as described above but we code disclosures including quantitative or financial information as three points, disclosures with company-specific information in a non-quantitative form as two points, and items disclosed in only general form as one point. Our quality of disclosure index is the standardized measure (it ranges from 0 to 1 ) calculated by dividing its disclosure score by the maximum score obtained in each year, across all firms.

\section{Monitoring Intensity}

In line with previous literature (e.g., Gillan 2006), we employ various measures (related to ownership structure and board of directors composition) to capture the monitoring intensity of the governance model. Data on ownership is obtained on courtesy of Thomson Financial. Following Roberts (1992), we measure ownership concentration as the percentage of shares held by investors holding more than $5 \%$. We also consider the role played by large institutional investors by considering the percentage of shares held by investment management funds (Johnson and Greening 1999).

Data on board composition are collected from the firms' annual reports and proxy statements. For each company it was possible to find the name and the type of directors (i.e., executive or independent non-executive director), a description of their role within the board (i.e., membership in a committee) and, in general, a brief biography. We measure board independence by the proportion of independent directors. The presence of CEO duality is measured by a dummy variable that takes the value of 1 if the CEO is also the chairman of the board and 0 otherwise.

\section{Stakeholders Orientation}

In line with the predictions of resource dependence theory, we consider various measures to capture the stakeholders' orientation of the governance model. We consider the presence and power of active institutional shareholders with a dummy variable (pension) equal to 1 if a pension fund is among top 10 investors (Johnson and Greening 1999; McGuire et al. 2003). In line with Sur et al. (2008), we also consider ownership diversity measured as the variance of the percentage of shares held by different types of investors. We measure the stakeholders' orientation of the board with several proxies. Board composition is measured by the proportion of community influentials. Community influentials are classified following Hillman et al. (2000): academicians, politicians (including retired politicians), military officers (including retired military officers), and members or directors of social/nonprofit organizations (including members of clergy and religious 
leaders). Community influentials are identified using the brief biographical note that is reported in the proxy statement. According to Coffey and Wang (1998), board diversity is defined as variation among its members. ${ }^{3} \mathrm{We}$ measure board diversity as the proportion of women sitting on the board. The strategic posture of the company has been proxied by previous literature (Cowen et al. 1987; Roberts 1992; Trotman and Bradley 1981) by referring to the board structure. We thus employ a dummy variable equal to 1 if the company has identified a director in charge of social responsibility issues or when boards have a committee in charge of CSR/ethics/sustainability matters, 0 otherwise. In order to measure relational capital, following Koenig and Gogel (1981), we use the average number of directorships held by non-executive directors.

\section{Measures of Corporate Social Performance}

Data on CSP are collected from the KLD's SOCRATES database, which is a comprehensive research database measuring the social performance of corporations. The web-based database ${ }^{4}$ contains social and environmental ratings indicators on the Business Ethics 100 Best Corporate Citizens for the years 2005, 2006, and 2007.

Companies are rated in seven CSP areas: Community, Corporate Governance, Diversity, Employee Relations, Environment, Human Rights, and Product Quality and Safety. For each area, KLD analysts assign 'strengths' and 'concerns' on a 5-point scale. Each area score is then determined by subtracting the concerns scores from the strengths scores. Data are collected in a disciplined process from a wide variety of company, government, and nongovernment organizations and media sources. Once the information is collected, KLD rates the social performance of companies using a proprietary framework of positive and negative indicators.

KLD data have been extensively used in the management literature on corporate social and environmental performance (see, e.g., Waddock and Graves 1997; Johnson and Greening 1999; Hillman et al. 2001; David et al. 2007) as well as recent social and environmental accounting research (see, e.g., Cho et al. 2006; Cho and Patten 2007; Cho et al. 2010).

Following Johnson and Greening (1999), we hypothesize two factors on the basis of the different components of the KLD database. The first factor is labeled as "people dimension" (community, employee relations, and human

\footnotetext{
3 Although diversity is a rich concept and would include gender, race, age, possible disabilities, etc., given the operational difficulties in proxying for such multiple aspects of diversity, we will rely only on the presence of women on the board, i.e., gender diversity, in line with Coffey and Fryxell (1991).

${ }^{4}$ http://www.business-ethics.com/BE100_all.
}

rights) and the second is labeled "product dimension" (environment, product). To adjust for possible industry effects we subtract the industry average for each of the five dimensions in the KLD databases from the individual scores for each dimension.

Table 2 summarizes the measurement of variables.

\section{Method}

We use structural equation modeling (SEM) to identify relationships between our variables (see Bollen 1989 for a comprehensive treatment on this topic). SEM is used to describe the directed dependencies among a set of variables, i.e., a multi-equation regression model in which the response variable in one regression equation may appear as a predictor in another equation. Some of the variables may be not observable (latent factors) and affected by measurement errors. In a nutshell, SEM exploits the causal relationship among variables that is typical for the path analysis, in which latent structures, commonly defined in the factor analysis are also considered. In particular latent variables are related to observables in the so-called measurement model whereas the structural equation model is a regression that defines the causal relation among the latent variables. Assuming the relations are linear and Gaussian distribution, inference can be performed through maximum likelihood. In this paper we used the SEM package implemented by Fox (2006) for the R language ( $\mathrm{R}$ development core team 2008). Furthermore, to deal with binary variables in the SEM setup, we computed heterogeneous correlation matrices among ordinal and numerical variables.

Figure 2 shows the hypothesized relations among the different proxies employed in our study. We control for firm's size, profitability, and industry effects.

In particular, the variables in rectangles are observed whereas variables in the ellipses are latent. Furthermore, the one-directional arrow indicates causal relation between variables, i.e., the regression coefficient, and bidirectional arrows indicate correlation. As usual in this literature, all the variables considered are characterized by measurement error.

\section{Results}

Descriptive Statistics and Correlation Analysis

Table 3 shows the descriptive statistics and correlation analysis for all variables of the companies in the sample.

On average, only $30.9 \%$ of our companies issue a sustainability report (untabulated). Approximately, $20 \%$ of the companies adopt the GRI standards. Companies issuing 
Table 2 Measurement of variables

\begin{tabular}{|c|c|}
\hline Model variables & Description \\
\hline \multicolumn{2}{|l|}{ Monitoring governance } \\
\hline Ownership concentration & $\%$ of shares held by major investors (above $5 \%$ ) \\
\hline Investment managers & $\%$ of shares held by investment management funds \\
\hline Board independence & Proportion of independents sitting on the board \\
\hline CEO duality & CEO duality (dummy $=1$ if CEO is also Chairman, 0 otherwise) \\
\hline \multicolumn{2}{|l|}{ Stakeholder governance } \\
\hline Pension funds & Dummy $=1$ if a pension fund is among top 10 investors, 0 otherwise \\
\hline Ownership diversity & Variance of $\%$ shares held by different type of investors \\
\hline Community influential & Proportion of community influentials sitting on the board \\
\hline Women directors & Proportion of women sitting on the board \\
\hline CSR committee & $\begin{array}{l}\text { Dummy }=1 \text { if there is CSR committee or Director in charge of CSR } \\
0 \text { otherwise }\end{array}$ \\
\hline Links with environment & Average no. of directorships of non-executive directors \\
\hline \multicolumn{2}{|l|}{ Social performance } \\
\hline \multicolumn{2}{|l|}{ People dimension } \\
\hline Community performance & KLD dimension for community performance \\
\hline Employee relations & KLD dimension for employee relations performance \\
\hline Human rights & KLD dimension for human rights performance \\
\hline \multicolumn{2}{|l|}{ Product quality dimension } \\
\hline Environmental performance & KLD dimension for environmental performance \\
\hline Product responsibility & KLD dimension for product responsibility performance \\
\hline \multicolumn{2}{|c|}{ Social and environmental disclosure variables } \\
\hline Extent of disclosure & $\%$ indicators as proposed by GRI \\
\hline Quality of disclosure & Content analysis quality score \\
\hline \multicolumn{2}{|l|}{ Control variables } \\
\hline Firm size & Log of total sales \\
\hline Firm profitability & Return on equity \\
\hline
\end{tabular}

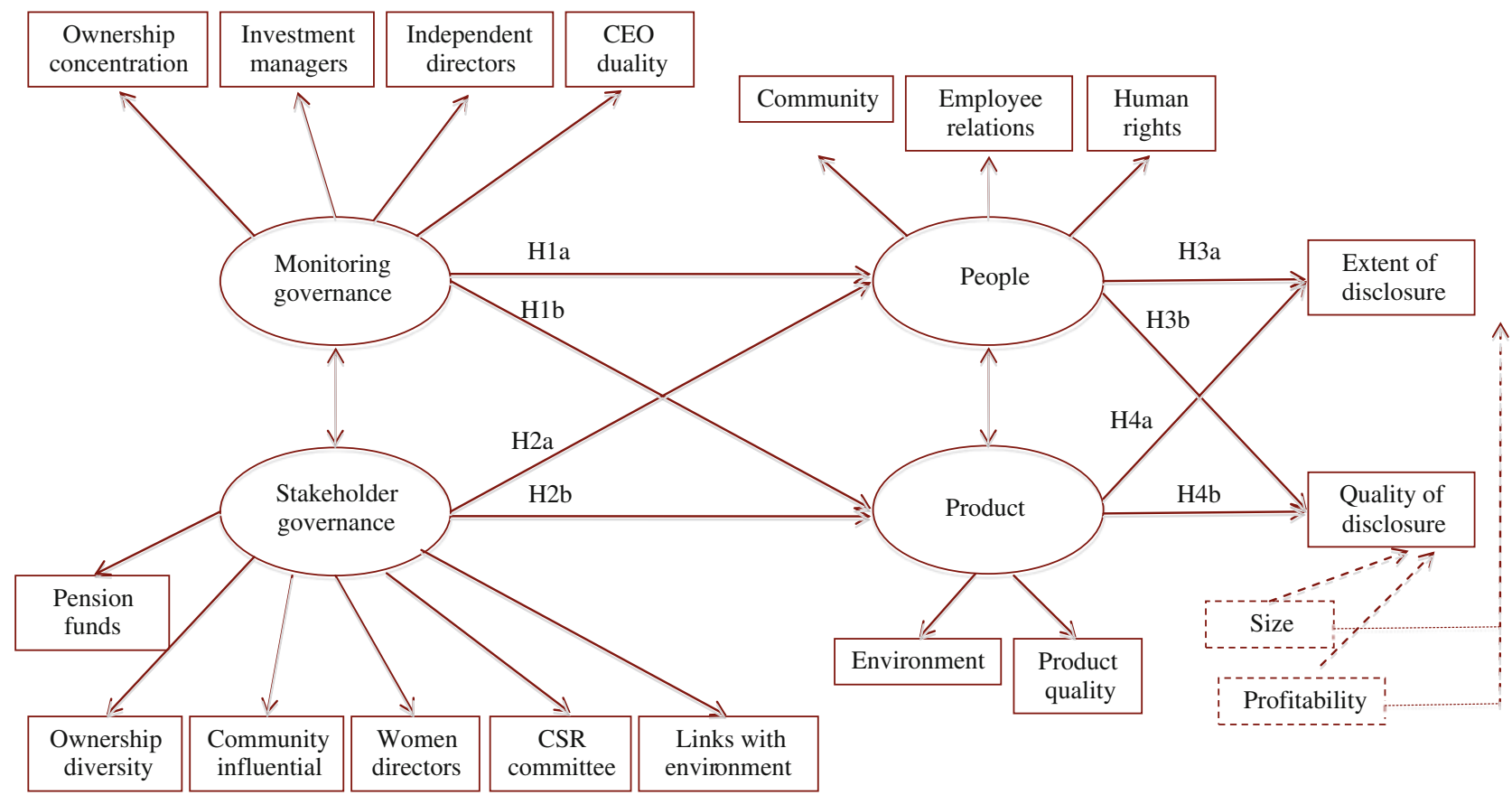

Fig. 2 Hypothesized relationships between the proxies 


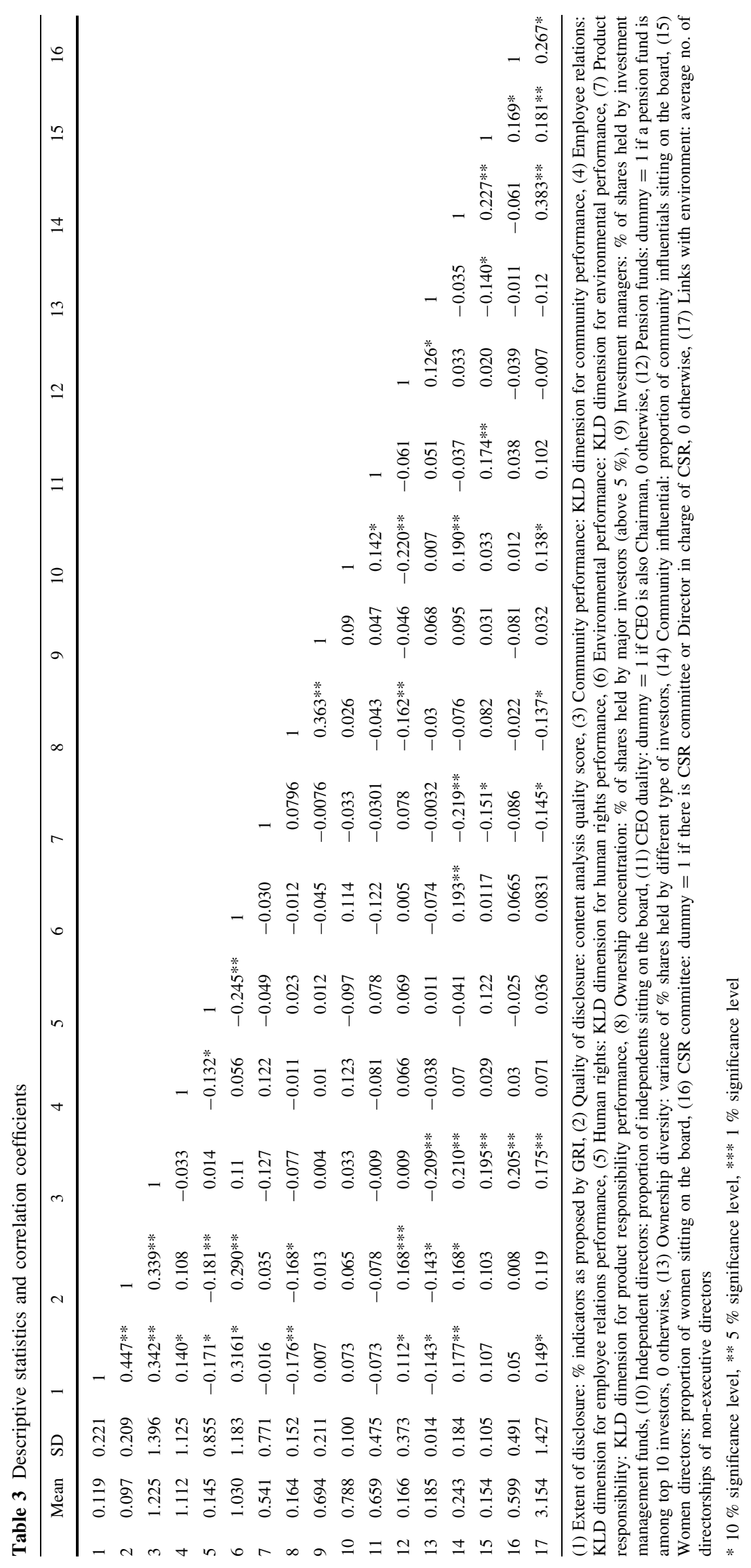


a sustainability report disclose information of only about $12 \%$ (measure 1 in Table 3 ) of the indicators proposed by GRI, although the maximum is 119 out of 121 . Given that we are analyzing Best Corporate Citizens, these results are quite surprising, as we would have expected a greater number of companies engaging in sustainability reporting. This first evidence goes in the direction predicted by sociopolitical theories of SED, which argues that worst performers would be more likely to use SED as a legitimacy tool.

On average, companies present a higher average of CSP along both the KLD community dimension (measure 3 in Table 3: the mean is 1.225 , and the maximum is almost 5.0) and employee relations (measure 4 in Table 3: the mean is 1.112 , and the maximum is 4.66). Major concerns can be identified in issues regarding human rights (measure 5: the mean is 0.145 , and the minimum is -4.29 ) and product quality and safety (measure 7 : the mean is 0.541 , and the minimum is -1.89 ). From the standard deviation data, we can also say that there seems to be great variation among companies in the sample about how they deal with the different CSR areas. The community and environmental issues present the largest variance. On the other hand, human rights and product quality and safety issues seem to be more uniformly managed (albeit at a lower level) by companies in the sample.

During the 3-year period, on average large investors (measure 8) own $16 \%$ of the shares. This highlights a degree of ownership concentration for the companies in the sample. Most of the shareholding is held by investment management companies (measure 9) $(69.4 \%)$. With regards to board variables, the mean proportion of independent directors (measure 10) is $78.8 \%$, CEO duality is quite a common practice given that during the 3 years on average $65.9 \%$ of companies have a CEO who is also the Chairman of the board of directors (measure 11). The mean proportion of community influentials (measure 14) is equal to $24.3 \%$, indicating that almost one in every four directors is a community influential. Women directors (measure $15)$ represent on average $15 \%$ of board members. Only in one case is the board made up of a majority of women directors (Student Loan Corporation in 2006). In $59.9 \%$ of cases, the companies have a CSR or Ethics Committee. On average, non-executives have 3.15 directorships in other companies (measure 17).

From the Pearson correlations for the variables used in our analysis, several statistically significant correlations emerge.

Ownership concentration appears to be significantly and negatively correlated with the level of adherence to GRI (our measure for extent of disclosure) and the quality disclosure score. No significant correlations are found between the proportion of shares held by investment institutions and measures of disclosure. The presence of pension funds is positively correlated both with the adoption of the GRI standards and disclosure quality. We also find evidence of significant correlations between board variables and measures of disclosure. The proportion of community influentials is significantly and positively correlated to all the measures of disclosure, while no significant associations are found between the proportion of women directors and disclosure. The average number of directorships is positively related to the extent of disclosure.

The community and environmental performance are significantly associated with all our measures of disclosure and the sign of the correlation coefficient is positive, suggesting that amongst the Best Corporate Citizens, the best performers are those more likely to present the greater number of disclosures and disclosures of higher quality. Employee relations performance is significantly associated only with the extent of disclosure, while human rights performance is negatively related to the disclosure measures.

\section{Structural Equation Model}

The results of the structural model are presented in Fig. 3. The goodness of fit indexes of the structural model support the fit between the structural model and the data, thus it suggests validity of the model.

There are many goodness-of-fit indicators for SEM models. Here we focus on the Bentler Comparative Fit Index (CFI), the Normed Fit Index (NFI), and the Root Mean Square Error of Approximation (RMSEA) that have been proved to be the most reliable in empirical research.

In particular, CFI compares the covariance matrix predicted by the model to the observed covariance matrix, and compares the null model (in which a null covariance matrix is assumed) with the observed covariance matrix. For our model, $\mathrm{CFI}=0.91$, and, as a rule of thumb, this indicator should be equal to or greater than 0.90 to accept the model, indicating that $90 \%$ of the covariation in the data can be reproduced by the given system. Similarly to the CFI index, the NFI compares the uncorrelated model with the given one. Here, we obtain the NFI equal to 0.92 that suggests an acceptable fit of the model. Finally, we consider RMSEA which is probably the most popular goodness-of-fit indicator used in empirical analysis. This indicator is in spirit different with respect to CFI and NFI since it is not based on the comparison between the given and a baseline model, but it is just based on the Chi-square of the model. Practitioners suggest that an RMSEA smaller than 0.06 suggests a good model fit. Concluding, all the indicators used affirm the adequate ability of the model to describe the dependencies among variables. 


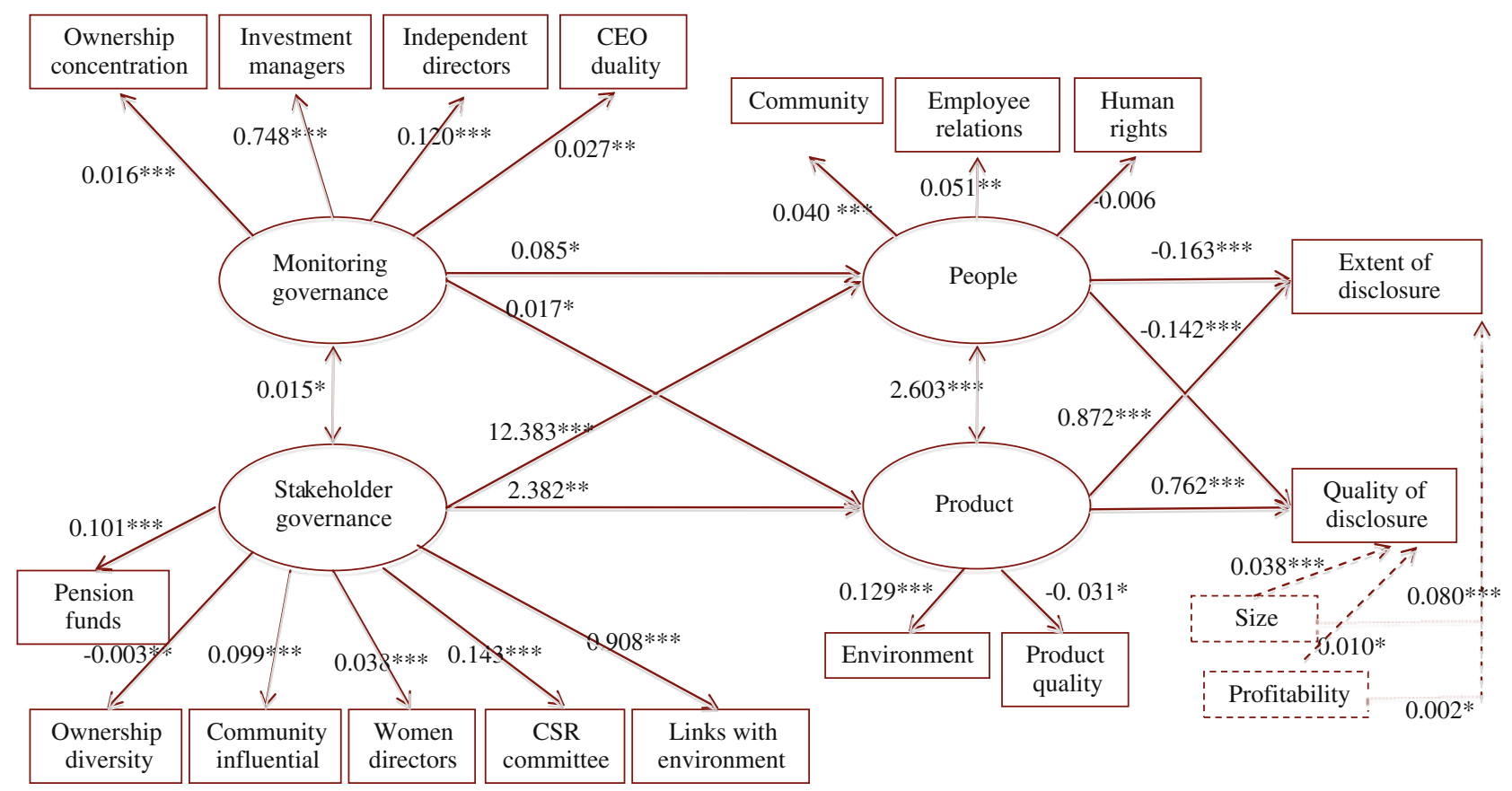

Fig. 3 Empirical findings. Goodness-of-fit index $=0.97$; Adjusted goodness-of-fit index $=0.91$; RMSEA index $=0.05$; Bentler-Bonnett $\mathrm{NFI}=0.92$; Bentler CFI $=0.91 ; * 10 \%$ significance level, $* * 5 \%$ significance level, $* * * 1 \%$ significance level

The path estimates are significant with some interesting evidence that we present below. We discuss and provide an interpretation of these results in the last section.

Firstly, all the coefficients linking observed and measurable governance variables to the latent ones are significant at $5 \%$ or more. The monitoring intensity is mainly driven by the presence of investment managers (the coefficient is equal to 0.748 at the $1 \%$ level) and the proportion of independent directors (the coefficient is equal to 0.120 at the $1 \%$ level), while the magnitude of the coefficients for CEO duality (0.027) and ownership concentration (0.016) indicate that these variables only marginally impact the monitoring intensity of corporate governance. The stakeholders orientation of corporate governance seems to be highly determined by the links with the environment (the coefficient is equal to 0.908 at the $1 \%$ significance level). Although the magnitude of the coefficients for the presence of a CSR committee (0.143) and pension funds (0.101) is lower, they still provide support for a role of these two attributes in positively enhancing the stakeholders' orientation of corporate governance. On the other hand, the magnitude of the coefficients for ownership diversity $(-0.003)$, the proportion of community influentials $(0.099)$, and the proportion of women directors $(0.038)$ indicate a much lower influence on the stakeholders' orientation of corporate governance. The results also provide evidence of a low covariance between the monitoring intensity and stakeholders' orientation of corporate governance (the coefficient is equal to 0.015 , at the $10 \%$ level).
Regarding the CSP latent variables, we obtain evidence that the performance in community and employee relations affects the people dimension, but the performance in human rights does not (the coefficient is not statistically significant). Also, the CSP in product dimension is mainly determined by environmental performance (statistical significance at $1 \%$ level), while the product quality performance negatively affects it (statistical significance at the $10 \%$ level). We also find evidence of a positive covariance between these two CSP variables.

With regard to the sign and values of the coefficients of interest, we have evidence that both governance attributes (monitoring intensity and stakeholders orientation) positively affect social performance (people and product), contrary to the prediction of agency theory that stronger monitoring would be associated with lower CSP. Nevertheless, the values and statistical significance of the two sets of coefficients vary. The coefficient linking monitoring intensity of corporate governance and people (product) performance is equal to $0.085(0.017)$ at the $10 \%$ significance level, while the coefficient linking the stakeholders' orientation latent variable to people (product) is equal to 12.383 (2.382) at the $5 \%$ level or higher. Taken together, these results provide support for $\mathrm{H} 2$ but not for $\mathrm{H} 1$.

Finally, Fig. 3 also shows the two sets of coefficients linking social performance and SED. We find that CSP in the product dimension is positively associated with the extent $(0.872$ at the $1 \%$ significance level) and quality ( 0.762 at the $1 \%$ significance level) of SED. Moreover, the 
analysis also shows evidence of a significant relationship between CSP in the people dimension. Interestingly enough, the coefficient linking CSP in people performance to the extent (quality) of disclosure is negative and equal to $-0.163(-0.142)$ at the $1 \%$ significance level.

Whilst these results would support $\mathrm{H} 3$, because CSP in the people dimension is negatively related to the extent of disclosure and for $\mathrm{H} 4$, because CSP in the product dimension is positively related to the quality of disclosure, at the same time-unexpectedly-they also falsify them.

We will discuss some interpretation of these results in the following section.

\section{Discussion and Conclusions}

The purpose of this study is to shed light on how corporate governance affects SED. In order to do so, we analyze the disclosures of the 100 U.S. Best Corporate Citizens in the period 2005-2007 and we posit a series of simultaneous relationships between different attributes of the governance system and a multidimensional construct of CSP. We consider both the extent and the quality of SED, with the purpose of identifying increasing levels of corporate commitment to disclosure and shedding some light on whether SED is used as a signal or rather as a legitimacy tool.

We find that the estimated coefficients linking both governance attributes to social performance are both positive, contrary to the prediction of agency theory that stronger monitoring would be associated with lower CSP. If we look at the magnitude of these coefficients compared to those linking the stakeholder orientation of corporate governance to CSP we notice that the intensity of this effect is much greater, in support of the enhanced stakeholder orientation hypothesis. This evidence is also in line with stakeholders' oriented governance being a substantive rather than a symbolic practice (Rodrigue et al. 2011). Substantive stakeholders oriented governance does bring organizational changes and therefore leads to improved social performance, whereas symbolic governance would only portray an image of commitment with no real impact on business operations. Therefore we have support for $\mathrm{H} 2$ but not for $\mathrm{H} 1$.

Our results seem to suggest that, contrary to what we would expect from agency theory, the monitoring mechanisms of corporate governance have a positive effect on the likelihood that companies commit to CSR and improve their performance. There are two possible explanations for this result. First, given that our observed monitoring variables are thought to limit managerial opportunism and protect shareholders' interests, in the case of the Best Corporate Citizens, improving CSR performance may indeed be in line with these goals. Second, it could also be that some of our monitoring proxies are indeed capturing not just the monitoring role of governance but also a reputation role. Previous literature argues, for example, that the presence of independent directors on the board increases the board's objectivity and its ability to represent multiple points of view of the firm's role in the environment and among stakeholders (Haniffa and Cooke 2005). Moreover, Johnson and Greening (1999) find empirical support for their hypothesis that outside directors' representation is positively associated with CSP. The theoretical argument behind these findings is that, by being more dedicated to stakeholders' expectations, independent directors will increase their own prestige and role in society and thus they would be more likely to encourage the company to undertake CSR activities. If independent directors are likely to respect the stakeholder obligations of the firm, they are more likely committed to stakeholder responsibility because in this way they increase the prestige and role in society (Zahra and Stanton 1988; Haniffa and Cooke 2005). Similar arguments are made with regard to CEO duality by organization theory, which claims that a strong leadership might be linked to legitimacy enhancement as it is signaling a clear direction to stakeholders.

With regards to our second set of hypotheses, interestingly enough, when we relate overall SED disclosure to performance on the "people" dimension, both coefficients are negative, suggesting that as performance in the people dimension increases, companies are more to likely provide both less and lower quality information, supporting the idea that disclosure is used as a legitimacy tool for poor social performance. This finding partially supports $\mathrm{H} 3$ but not $\mathrm{H} 4$. On the other hand, when we relate overall SED disclosure to the product dimension, these coefficients are positive suggesting that firms performing well in the product dimension used disclosure as a way to signal their superior performance, both by providing a greater extent of information and information of better quality. With reference to the product dimension therefore we have support for $\mathrm{H} 4$ but not $\mathrm{H} 3$.

Overall, our evidence suggests that while SED is used as a signal to communicate superior performance in the "product" dimension to external stakeholders, it is also used as a legitimacy tool when companies are performing poorly in the "people" dimension. An interpretation of these unexpected results might be linked to the different levels of societal concern with environmental versus social issues, which might shape the relationship between disclosure and underlying performance.

The "product" dimension includes corporate environmental performance, for which there is more publicly available data (for example, the Toxic Release Inventory, the Environmental Protection Agency, etc.) and measures 
are more objective (greenhouse gas emissions, waste recycled, etc.). Because of this greater objective and standardized measurability of environmental issues, this type of disclosure is relatively easier to verify. Moreover, as companies face greater societal pressure with regard to environmental issues, this seems to push companies to present greater and better disclosure, in order to manage stakeholders' scrutiny. This suggests the use of disclosure to signal the superior social performance of the company and as an accountability mechanism.

On the other side, the "people" dimension is characterized by more uncertainty and fuzziness both in terms of which issues are to be considered important and which measure better depicts the performance of firms. This means that although stakeholders' pressure might be high, the reliability of the disclosures made by firms is also harder to discuss and evaluate. Thus, in the context of the "people" dimension, companies are more likely to use disclosure as legitimacy rather than as an accountability mechanism.

Our findings have implications for both directors of companies and the companies' stakeholders. There is a new emphasis on the role of boards of directors in setting social and environmental objectives which meet the evolving expectations of a firm's stakeholders. Our study highlights the impact that different aspects of corporate governance might have and, in turn, the ways in which a board's actions in relation to CSP may affect accountability policies.

We believe that our study contributes to the governance literature by showing that the corporate governance path leading to SED can be traced, but it is indeed a complex rather than a straightforward route. However, by considering the interplays between different governance attributes and CSP, and using SEM techniques, we have shed some light on this important area. We believe our research is timely and helps fill a significant lacuna in the literature as it provides important insights to corporate boards, shareholders, stakeholders, and regulators who all have an increasing interest in this area.

Like all studies, ours is not without its limitations. First, our sample is the Best Corporate Citizens who may be more disposed towards improving CSR performance (although companies generally do seem to be placing more emphasis on CSR aspects). Secondly, we only focus on a single country and institutional setting. Therefore, further research could focus on an international comparison to show whether the legal, cultural, and institutional environments affect this complex set of relationships.

Acknowledgments The authors thank Thomas Clarke (Corporate Governance Section Editor), the referees, Charles Cho, the participants to the 1st French Congress on Social and Environment Accounting Research and at the research workshop at Concordia University for their valuable comments and feedback.

\section{References}

Abbott, W., \& Monsen, R. (1979). On the measurement of corporate social responsibility: Self-reported disclosures as a method of measuring corporate social involvement. Academy of Management Journal, 22(3), 501-515.

Al-Tuwaijri, S., Christensen, T. E., \& Hughes, K. E. (2003). The relations among environmental disclosure, environmental performance, and economic performance: A simultaneous equations approach. Accounting, Organizations and Society, 29(5-6), 447-471.

Belkaoui, A., \& Karpik, P. G. (1989). Determinants of the corporate decision to disclose social information. Accounting, Auditing and Accountability Journal, 2(1), 36-51.

Berle, A. A., \& Means, G. C. (1932). The modern corporation and private property. New York: Macmillan.

Bollen, K. A. (1989). Structural equations with latent variables. New York: Wiley.

Bondy, K., Matten, D., \& Moon, J. (2008). Multinational corporation codes of conduct: Governance tools for corporate social responsibility? Corporate Governance an International Review, 16(4), 294-311.

Bowman, E. H., \& Haire, M. (1975). A strategic posture toward corporate social responsibility. California Management Review, 18(2), 49-58.

Buckholtz, A. K., Brown, J. A., \& Shabana, K. M. (2008). Corporate governance and corporate social responsibility. In A. Crane, A. McWilliams, D. Matten, J. Moon, \& D. S. Siegel (Eds.), The Oxford handbook of CSR (pp. 327-345). Oxford: Oxford University Press.

Cespa, G., \& Cestone, G. (2007). Corporate social responsibility and managerial entrenchment. Journal of Economics and Management Strategy, 16(3), 741-771.

Cho, C., \& Patten, D. M. (2007). The role of environmental disclosures as tools of legitimacy: A research note. Accounting, Organizations and Society, 32(7-8), 639-647.

Cho, C. H., Patten, D. M., \& Roberts, R. W. (2006). Corporate political strategy: An examination of the relation between political expenditures, environmental performance, and environmental disclosure. Journal of Business Ethics, 67(2), 139-154.

Cho, C. H., Roberts, R. W., \& Patten, D. M. (2010). The language of US corporate environmental disclosure. Accounting, Organizations and Society, 35(4), 431-443.

Clarkson, P. M., Li, Y., Richardson, G. D., \& Vasvari, F. P. (2008). Revisiting the relation between environmental performance and environmental disclosure: An empirical analysis. Accounting, Organizations and Society, 33(4/5), 303-327.

Coffey, B. S., \& Fryxell, G. E. (1991). Institutional ownership of stock and dimensions of corporate social performance. Journal of Business Ethics, 10(6), 437-444.

Coffey, B. S., \& Wang, J. (1998). Board diversity and managerial control as predictors of corporate social performance. Journal of Business Ethics, 17(14), 1595-1603.

Cowen, S. S., Ferreri, L. B., \& Parker, L. D. (1987). The impact of corporate characteristics on social responsibility disclosure: A typology and frequency-based analysis. Accounting, Organizations and Society, 12(2), 111-122.

Cox, P., Brammer, S., \& Millington, A. (2004). An empirical examination of institutional investor preferences for corporate social performance. Journal of Business Ethics, 52, 27-43.

David, P., Bloom, M., \& Hillman, A. (2007). Investor activism managerial responsiveness, and corporate social performance. Strategic Management Journal, 28, 91-100.

Deephouse, D. L. (2000). Media reputation as a strategic resource: An integration of mass communication and resource-based theories. Journal of Management, 26(6), 1091-1112. 
Fama, E. F., \& Jensen, M. C. (1983). Separation of ownership and control. Journal of Law and Economics, 26, 301-325.

Fox, J. (2006). Structural equation modeling with the SEM Package in R. Structural Equations Modelling, 13(3), 465-486.

Freedman, M., \& Jaggi, B. (1982). Pollution disclosures, pollution performance and economic performance. OMEGA, 10(2), 167-176.

Freeman, R. E. (1984). Strategic management: A stakeholder approach. Boston: Pitman.

Gales, L. M., \& Kesener, I. F. (1994). An analysis of board of director size and composition in bankrupt organisations. Journal of business research, 30(3), 271-282.

Gillan, S. L. (2006). Recent developments in corporate governance: An overview. Journal of Corporate Finance, 12(3), 381-402.

Global Corporate Governance Forum. (2009). Corporate governance: The foundation for corporate citizenship and sustainable businesses. Washington DC: GCGF.

Graves, S. B., \& Waddock, S. A. (1994). Institutional owners and corporate social performance. Academy of Management Journal, 37(4), 1034-1046.

Gray, R., Kouhy, R., \& Lavers, S. (1995). Corporate social and environmental reporting: A review of the literature and a longitudinal study of UK disclosure. Accounting, Auditing and Accountability, 8(2), 47-77.

Guidry, R. D., \& Patten, D. M. (2010). Market reactions to the firsttime issuance of corporate sustainability reports: Evidence that quality matters. Sustainability Accounting, Management and Policy Journal, 1(1), 33-50.

Guthrie, J., \& Parker, L. D. (1990). Corporate social disclosure practice: A comparative international analysis. Advances in Public Interest Accounting, 3, 159-175.

Hackston, D., \& Milne, M. (1996). Some determinants of social and environmental disclosures in New Zealand. Accounting Auditing and Accountability Journal, 9(1), 77-108.

Haniffa, R. M., \& Cooke, T. E. (2005). The impact of culture and governance on corporate social reporting. Journal of Accounting and Public Policy, 24(5), 391-430.

Hillman, A. J., Cannella, J., \& Paetzold, A. A. (2000). The resource dependence role of corporate directors: Strategic adaptation of board composition in response to environmental change. Journal of Management Studies, 37(2), 235-255.

Hillman, A. J., \& Dalziel, T. (2003). Boards of directors and firm performance: Integrating agency and resource dependence perspectives. Academy of Management Review, 28, 383-396.

Hillman, A. J., Keim, G. D., \& Luce, R. A. (2001). Board composition and stakeholder performance: Do stakeholder directors make a difference? Business and Society, 40(3), 295-314.

Huse, M. (2003). Renewing management and governance: New paradigms of governance? Journal of Management and Governance, 7(3), 211-221.

Jensen, M. C., \& Meckling, W. M. (1976). Theory of the firm: Managerial behavior agency costs, and ownership structure. Journal of Financial Economics, 3, 305-360.

Johnson, R., \& Greening, D. (1999). The effects of corporate governance and institutional ownership on corporate social performance. Academy of Management Journal, 42, 564-580.

Koenig, T., \& Gogel, R. (1981). Interlocking corporate directorships as a social network. American Journal of Economics and Sociology, 40, 37-50.

Krippendorff, K. (2004). Content analysis. Thousand Oaks, CA: Sage.

Lindblom, C. K. (1994). The implications of organizational legitimacy for corporate social performance and disclosure. Paper presented at the Critical Perspectives of Accounting Conference, New York.

Luoma, P., \& Goodstein, J. (1999). Stakeholders and corporate boards: Institutional influences on board composition and structure. Academy of Management Journal, 42, 553-563.
Mallin, C., \& Michelon, G. (2011). Board reputation attributes and corporate social performance: An empirical investigation of the US Best Corporate Citizens. Accounting and Business Research, 41(2), 119-144.

McGuire, J., Dow, S., \& Argheyd, K. (2003). CEO incentives and corporate social performance. Journal of Business Ethics, 45(4), $341-359$

Michelon, G., \& Parbonetti, A. (2010). Stakeholder engagement: Corporate governance and sustainability disclosure. Journal of Management and Governance. doi:10.1007/s10997-010-9160-3.

Minichilli, A., Zattoni, A., \& Zona, F. (2009). Making boards effective: An empirical examination of board task performance. British Journal of Management, 20, 55-74.

Mintzberg, H. (1983). Power in and around organizations. Englewood Cliffs, NJ: Prentice-Hall.

Neubaum, D. O., \& Zahra, S. A. (2006). Institutional ownership and corporate social performance: The moderating effects of investment horizon, activism, and coordination. Journal of Management, 32, 108-131.

OECD (Organization for Economic Co-operation and Development). (2004). OECD principles of corporate governance. www.oecd.org.

OECD (Organization for Economic Co-operation and Development). (2010). Corporate Responsibility: Reinforcing a Unique Instrument-2010 Annual Report on the OECD Guidelines for Multinational Enterprises. www.oecd.org.

Patten, D. M. (1991). Exposure, legitimacy, and social disclosure. Journal of Accounting and Public Policy, 10(4), 297-308.

Patten, D. M. (1992). Intra-industry disclosure in response to the Alaskan oil spill: A note on legitimacy theory. Accounting, Organizations and Society, 17(5), 471-475.

Patten, D. M. (2002). The relation between environmental performance and environmental disclosure: A research note. Accounting, Organizations and Society, 27(8), 763-773.

Pfeffer, B. R., \& Salancik, J. (1978). The external control of organizations: A resource dependence perspective. New York: Harper \& Row.

Provan, K. G. (1980). Board power and organizational effectiveness among human service agencies. Academy of Management Journal, 23, 221-236.

Pugliese, A., Bezermer, P., Zattoni, A., Huse, M., Van den Bosch, F. A. J., \& Volberda, W. (2007). Board of Directors' contribution to strategy: A literature review and research agenda. Corporate Governance: An International Review, 17(3), 292-306.

R Development Core Team (2008). R: A language and environment for statistical computing. Vienna, Austria: R Foundation for Statistical Computing.

Roberts, R. (1992). Determinants of corporate social responsibility disclosure: An application of stakeholder theory. Accounting, Organizations and Society, 17(6), 595-612.

Rodrigue, M., Magnan, M., \& Cho, C. (2011). Greening or Greenwashing: Does environmental governance matter? Paper presented at the 3rd CSEAR Conference North American, Montreal, Canada.

Sacconi, L. (2006). A social contract account for CSR as an extended model of corporate governance (I): Rational bargaining and justification. Journal of Business Ethics, 68(3), 259-281.

Selznick, P. (1949). TVA and the grass roots. Berkeley, CA: University of California Press.

Sur, S., Livna, E., \& Magnan, M. (2008, June). Why do boards differ? Exploring ownership effects on board composition. Paper presented at the Administrative Sciences Association of Canada.

Surroca, J., \& Tribò, J. A. (2008). Managerial entrenchment and corporate social performance. Journal of Business Finance and Accounting, 35(5-6), 748-789.

Trotman, K., \& Bradley, G. W. (1981). Associations between social responsibility disclosure and characteristics of companies. Accounting, Organizations and Society, 6(4), 355-362. 
Ullman, A. (1985). Data in search of a theory: A critical examination of the relationship among social performance, social disclosure, and economic performance. Academy of Management Review, 10(3), 540-577.

Verecchia, R. E. (1983). Discretionary disclosure. Journal of Accounting and Economics, 5, 179-194.

Waddock, S. A., \& Graves, S. B. (1997). The corporate social performance-financial performance link. Strategic Management Journal, 18(4), 303-319.
Zahra, S. A., \& Pearce, J. A. II (1989). Boards of Directors and corporate financial performance: A review and integrative model. Journal of Management, 15(2), 291-334.

Zahra, S. A., \& Stanton, W. W. (1988). The implications of Board of Directors' composition for corporate strategy and performance. International Journal of Management, 5(2), 229-236.

Zattoni, A. (2011). Who should control a corporation? Toward a contingency stakeholder model for allocating ownership rights. Journal of Business Ethics, 103, 255-274. 